\title{
Community and Communitarianism in Toni Morrison: Restoring the Self and Relating with the Other
}

\author{
TaeJin Koh ${ }^{1, *(1)}$ and Saera Kwak ${ }^{2}$ \\ 1 Department of Indian Studies, College of Asian Languages and Cultures, Hankuk University of \\ Foreign Studies, Seoul 02450, Korea \\ 2 Department of Persian and Iranian Studies, College of Asian Languages and Cultures, Hankuk University of \\ Foreign Studies, Seoul 02450, Korea; saera_kwak@hufs.ac.kr \\ * Correspondence: india@hufs.ac.kr; Tel.: +82-2-2173-8804
}

Citation: Koh, T.; Kwak, S.

Community and Communitarianism in Toni Morrison: Restoring the Self and Relating with the Other. Societies 2021, 11, 57. https://doi.org/ $10.3390 /$ soc 11020057

Academic Editor: Gregor Wolbring

Received: 19 April 2021

Accepted: 4 June 2021

Published: 6 June 2021

Publisher's Note: MDPI stays neutral with regard to jurisdictional claims in published maps and institutional affiliations.

Copyright: (C) 2021 by the authors. Licensee MDPI, Basel, Switzerland. This article is an open access article distributed under the terms and conditions of the Creative Commons Attribution (CC BY) license (https:/ / creativecommons.org/licenses/by/ $4.0 /)$.

\begin{abstract}
Toni Morrison discusses the rebirth of the entire Black race through self-recovery. However, her novels are not limited to the identity of Black women and people but are linked to a wider community. Morrison might have tried to imagine a community in which Black identity can be socially constituted. In this paper, we discuss the concept of community by examining communitarianism, which is the basis of justice and human rights. Although community is an ambiguous notion in the context of communitarianism, communitarians criticize the abstract conceptualization of human rights by liberal individualists, but also see that human rights are universally applicable to a community as a shared conception of social good. Communitarianism emphasizes the role and importance of community in personal life, self-formation, and identity. Morrison highlights the importance of self-worth within the boundary of community, reclaiming the development of Black identity. In the Nancian sense, a community is not a work of art to be produced. It is communicated through sharing the finitude of others-that is, "relation" itself is the fundamental structure of existence. In this regard, considering Toni Morrison's novels alongside communitarianism and Nancy's analysis of community may enable us to obtain a sense of the complex aspects of self and community. For Morrison, community may be the need for harmony and combination, acknowledging the differences and diversity of each other, not the opposition between the self and the other, the center and periphery, men and women. This societal communitarianism is the theme covered in this paper, which deals with the problem of identity loss in Morrison's representative novels Sula and Beloved and examines how Black individuals and community are formed. Therefore, this study aims to examine a more complex understanding of community, in which the self and relations with others can be formed, in the context of Toni Morrison's works.
\end{abstract}

Keywords: Toni Morrison; community; communitarianism; the inoperative community; human rights

The fathers may soar

And the children may know their names (Song of Solomon, epigraph)

\section{Introduction}

What is justice? In recent years, Korean academics have emphasized communitarianism as the most important consideration when dealing with justice and human rights [1] Communitarians emphasize the role and importance of community in personal life, selfformation, and identity, because a community has inherent moral values as a means of promoting and protecting individual freedoms and rights [2]. However, individualists argue that this community has the potential to suppress or eliminate individual freedoms and rights, and that the community exists only for the welfare of individuals and has no inherent, independent moral value of its own [3]. The basic view of communitarianism has been systematized by scholars who adhere to the philosophies of Aristotle and Hegel and debated with liberalists [4-7]. Communitarians not only criticize the individualist 
tendencies of liberalism, which play a role in the community in self-formation, but also do not have the same views of the concept of community, the character of community, and the relation between the individual and community.

Communitarianism, in general, denies universal moral values, unlike universalism and individualism; recognizes specific ethical norms that are relevant to specific communities; and attaches importance to the sense of belonging and loyalty to specific communities rather than love, devotion, and loyalty to the entirety of humanity. Self-identity or the self are formed based on the history and tradition of a specific community. According to MacIntyre, self-identity should be shaped in consideration of the inherent history and traditions of the society in which an individual belongs [4]. In this way, communitarianism requires more active acceptance of the values and ethics of the specific community to which individuals belong rather than of universal moral values. However, individualism accepts that all human beings are created equal and have inalienable rights. Individualism is often traced to the doctrine of liberalism; therefore, liberal individualism is usually criticized by communitarianism through its promotion of community [8] (p. 3).

The concept of community can be ambiguous, although it serves as a basis for social relations, identity formation, the formulations of some social and political institutions, and moral duties. A community is a small or large society that has something in common, such as norms, interests, values, or identity. Many scholars have tried to examine the types of community and a sense of community [9], [10] (pp. 9-14), [11-13], Nevertheless, we should also note that a community is made up of a group of individuals. There is an intersection between a set of shared values as well as different sets of objectives held by individuals in a community. However, some social institutions of community play a role in coordinating competing values and activities. If social institutions do not properly work on social, political, and economic levels, one individual becomes dominant, and others become oppressed. Therefore, social codes or laws are introduced in societies as a framework for a legal system so that individuals do not harm each other. Nevertheless, humans are often deprived of human rights, as it is not about the institutional problems of the society but about the concept of community. In fact, the term "community" is used everywhere without having a common and specific meaning.

Communitarianism and individualism are also closely related to how human rights are interpreted in a community. Many communitarians, except for MacIntyre, criticize the abstract concept of human rights in liberal individualism, but also see that human rights are universally applicable to a community as a shared concept of social good. This is because natural or human rights are fictions-just as utility is - but fictions with highly specific properties [4] (p. 70). Walzer, in contrast to the concept of human rights based on common humanity supported by individualists, argued that human rights should be based on shared concepts of social good [6]. He claimed that the human rights of individualism and universalism as an equitable and unequal concept are unrealistic and abstract. He also stated that human rights can be guaranteed only within the community and within the limits of community members. Nevertheless, as with universalism, communitarians also agree that there is a duty to guarantee the basic right of life and human rights, but that this is a secondary responsibility for aliens, and that the obligation to be limited within the community is the primary duty. In other words, aliens who are not part of the community can sometimes be helped through charity, but this is not a moral obligation, but a secondary duty. Moreover, MacIntyre claims that human rights are the same as a belief in witches or unicorns [4] (pp. 69-70). In his interpretation, human rights are synonymous with natural rights. He denies human rights or natural rights, arguing that there are no fundamental and inalienable protections to human beings.

I mean those rights which are alleged to belong to human beings as such and which are cited as a reason for holding that people ought not to be interfered with in their pursuit of life, liberty, and happiness. They are the rights which were spoken of in the eighteenth century as natural rights or the rights of man. [4] (pp. 68-69) 
However, that does not mean that human rights are purely rhetorical. Although MacIntyre is considered a communitarian, he also stated that, "Aristotle gave us excellent reasons for believing that both rational enquiry in politics and ethics and rationality in action require membership in a community which shares allegiance to some tolerably specific overall conception of the ultimate human good " [4] (p. 99). It seems that human rights are substantive and embodied rather than a procedural and deracinated understanding of ethics [14] (p. 209).

The discourse on human rights in communitarianism has contributed to expanding the horizon of human rights discourse by emphasizing the importance of community, which individualism and universalism overlook, and especially the ethical significance of the boundaries of community [15]. However, this view is very ambiguous in defining the boundary or scope of community and categories of community members. It is sometimes based on national boundaries and is also limited to people who share a common language and semantics. In this context, the concept of community according to communitarians might be an imagined community.

Jean-Luc Nancy introduced the term "the inoperative community" (La Communauté Désœuvrée) to describe a community that is not a work of art (artifice) to produce [16]. In his view, the truth of community, on the contrary, resides in the retreat of such a being [16] (p. 39). He argued that the best way to fight disintegration is to return to the period in which the communal bonds were present, or to make an effort to build a future community where communal ties can be restored. In fact, the original community in Nancy's view is not a reference in our history, but rather a mythical or imaginary concept. Therefore, the identity of community is close to the mythology of "immanentism", which makes the nature of community absolute within it. He criticizes totalitarianism and communism. According to Nancy, individuals are always "being-with", but this being-with is no longer a substantial "being-together" [16]. He explains that individuals exist together and existing means being-with.

Justice and human rights may eventually possess the characteristics of communitarianism, self-restoration, and identity that have formed and evolved in the process of recognizing and solving the problems of the times. Moreover, the historical background itself cannot define the political consciousness and mode of action of human beings in recognizing and solving the problems of their times; rather, it is universal values - that is, human rights-that can ultimately lead to community development based on individual equality.

In this aspect, Toni Morrison's novels discuss racial self-denials of the Black community, as well as the racial issues of Black and White, centered on Black women suffering from the oppressive structure of sex and class within a Black community.

The white myth, symbolized by white skin, blond hair, and blue eyes, especially in The Bluest Eye, describes the confusion and fragmentation of the Black community in a society in which the white-centered value system is strictly imposed. If in The Bluest Eye, a Black woman shows the process of blindly internalizing a white male-centered identity, Sula contrasts this with a new sexual identity against the patriarchal norm of Black women in the Black community and shows the process of its acquisition. In other words, unlike The Bluest Eye, which illustrates the discrimination and opposition to Black women in White, male-centered culture and the issue of Black women's self and sexual identity in the Black community, Sula depicts the psychological conflicts within the Black community and its members' identity confusion.

Beloved tells a story of a Black woman recovering, as well as portraying the sufferings and adversity of Black slaves and suggesting ways for Black slaves to overcome the past and restore their damaged identity. Black men have been deprived of their masculinity and turned into incompetent individuals who have failed to even preserve their homes. Black women have been abused by racial sexual exploitation in a double exploitation structure, and even their motherhood, which is a basic right, is oppressed. In other words, Morrison explores the rebirth of the entire Black race through self-recovery. However, Toni Morrison's novels are not limited to the identity of Black women and Black people. A Mercy, 
published in 2008, describes a new way of dealing with the various aspects of life that many races faced in the late 17th century, before the United States was formed. Morrison discusses the origins and identity of America through various categories of different races in early American society.

In this way, we will explore the concept of community, which is the basis of justice and human rights, by examining the importance of equality and the coexistence of the community across racial, gender, and class lines in the novels of Toni Morrison, a Black American woman writer. Considering Toni Morrison's novels alongside communitarianism and Nancy's analysis of community may enable us to obtain a sense of the complex aspects of self and community. For Morrison, a community may be the need for harmony and combination, acknowledging the differences and diversity of each other, and not the opposition between the self and the other, the center and periphery, men and women. Toni Morrison aims to establish harmony and coexistence within the community, in addition to recovering the identity of individual human beings, not Black women. This societal communitarianism is the theme covered in this paper, which deals with the problem of identity loss in Toni Morrison's representative novels, Sula and Beloved, and examines how individuals, not as Black but as human beings, and communities are formed.

\section{Self-Restoration as a Black Woman in Sula}

Toni Morrison not only maintained the basic position of other writers who want to preserve their Black heritage and establish their identity, but also broadened the horizons of Black literature by applying women's perspectives. Sula is a novel about Black women who try to find their most radical self, showing how the search for Black women's identity can be realized. Sula deals with the relationship between two women, Nell Wright and Sula Peace, focusing on the inside of a Black community, Bottom, in Medallion. Bottom is a typical village that has been created and marginalized by White people in a racist society. In this closed space, Black men are disgruntled with the self-seeking of Black women.

Nell is a Black woman who loses her voice. She is passive in the oppressive and closed Black community and believes that sacrifice and service are women's virtues. Sula, unlike Nell, rejects passive life and pursues an independent life with a strong self-consciousness, but her life also illustrates the distortion of the self, coming from not embracing others. Sula represents a complex, inconsistent, and fluid self that goes beyond the general idea of the self. The self-respect of Black women entails the embodiment or realization of the self. In addition, the various images imposed on Black women are distorted by the act of threatening the existing power of society [17].

Those who do not conform to the dominant hegemony are treated as "other" by the dominant portion of society. This feeling of otherness and being marginalized causes many social, psychological, and personal conflicts [18] (p. 46). In Sula, the poem "The Rose Tattoo" is quoted in the preface. This serves as an indication that Sula's survival means transcendental life as a Black woman. Thus, the existence of Sula in the transcendental sense is always an act or behavior of thesis as well as antithesis. Her freedom is related to the oppression of others in conflict with the freedom of others and the empowerment of the self. Thus, Sula's life is irrelevant to the mutualistic sympathy or social altruism that binds the other with the self until death. In other words, the novel shows the impact of the self that is antisocial and closed on the community. However, the difference between her life and gender consciousness does not exist as an object of moral judgment.

Although Sula brought unity to the village by being a public enemy and symbol of immorality in her lifetime, after Sula's death, the communal unity of Bottom lost power. Morrison introduces Shadrack, a Black youth, to raise the issues of the collapse of the Black community as well as the otherness of Sula. He is a young Black man who returned to Medallion in 1917 after serving in the war at the age of twenty. He is trapped in the trauma of war because he suffered the shock of watching his friend dying near him. In other words, Shadrack is a Black man who, regardless of his will, served in the war as a protector of the social system that White people created and lost his identity. He lives miserably in the 
Black community without being cared for or assimilated. However, Shadrack's cottage, as discovered by Sula, was clean and orderly. This implies the purity of Black people as a sign that Shadrack was not invaded by White culture. Shadrack, who was not even convinced of his existence because of the psychological impact of the war, begins to feel the reality of his identity starting from when he identifies himself in the world.

Sula pursues her own independent and new identity and completely disconnects herself from the community in order to confront the power of submitting herself to any fixed customary system. Nell, who has another type of identity compared to Sula, likes to emphasize that, "the traditional African American community is not ready to accept a woman who assumes a man's freedom" [19] (p. 519). However, Nell's idea has no effect on Sula.

Nell becomes exasperated with her arrogance, with her still smart talking while lying at death's door. "Why? I can do it all, why can't I have it all?"

"You can't do it all. You a woman a colored woman at that. You can't act like a man. You can't be walking around all independent-like, doing whatever you like, talking what you want, leaving what you don't." (Sula, p. 142)

Sula believes that Black women can have the same thoughts and actions as men, and she strongly advocates to Nell the unfairness of the patriarchal values of the male dominance prevalent in the Black community. This is why Sula, after her death, was still inevitably rejected by the Black community. However, as can be seen below, Sula's death still seems to have something to do with it. This does not mean the end, but her spirit and power have the potential to change the authority and values of the Black community. In other words, the existing values pursued by the Black community, represented by Nell, and the independent and new values pursed by various individuals, represented by Shadrack and Sula, still seem to remain unresolved. Morrison shows that the self and the other are not fixed but have independent spaces.

When Nell visits Eva, Nell truly understands Sula through Sula's absence. Eva asks her about Chicken Little's death. Eva does not admit that Chicken Little's death is irrelevant and is entirely due to Sula. Nell breaks their relationship by remaining distant from Sula. Additionally, they realize that it was the death of Chicken Little that forcibly separated Sula from the Black community. In other words, by recognizing the point at which Sula became the other or was typified and her identity isolated, Nell understands Sula's belief and acquires her identity.

And the loss pressed down on her chest and came up to into her throat. "We was girls together." She said as though explaining something, "O Lord, Sula." She cried, "girl, girl, girlgirlgirl." It was a fine cry_loud and long—but it had no bottom, and it had no top, just circles and circles of sorrow. (Sula, p. 174)

Thus, the process of memory and mourning for Sula leads to self-recovery, and, furthermore, lays a groundwork for relating to the other [20] (p. 110). Sula deals with the friendship between two African American women, but Watkins regards this friendship as the essence of a Black female's identity [21] (p. 178). Morrison spoke about the relationship between Nell and Sula in an interview, as below:

"In 'Sula' I tried to posit a situation where there was a so-called good and a so-called evil people. Nell and Sula are symbolic of this condition. And of course, you can't always tell which is which. Nell is the kind of person I like because I like people who 'do it'. No matter what happens, they do what they must do. She will take care of the children and do the work but will never have the fire and the glory or the glamour. But the bread will be there. Nobody ever thinks about these people. So, they just sit on buses and carry the weight of the world forever. Nell has limitations and she does not have the imagination that Sula has. On the other hand, I also like people like Sula. They are exciting, and they are willing to trust their instincts completely which is what Sula does. She has absolutely no plans for any series of moments. Yet she and Nel are very much 
like. They complement each other. They support each other. I suppose the two of them together could have made a wonderful single human being. But, you see, they are like a Janus' head". [22] (p. 62)

Morrison notes that Black women have always been a solid backbone to each other and that they need each other to survive physically and mentally in a situation where no one can depend on themselves. Sula's death is tragic, but Morrison reveals how powerful the dominant social system is through the limits of Sula's experimental life. At the same time, this shows vividly how difficult it is for an individual or community to maintain their inner self when racism is omnipresent. Morrison does not advocate either Sula's experimental freedom or Nell's traditional obedience. Sula and Nell are complementary to each other rather than coincident. Although Sula pursues individual freedom or identity, this is not an individualistic immersion in one's own emotions and thoughts, excluding others, but a self-formation within the community of Black women or within Black community. Communitarians argue that the pursuit of an individual's sense of identity or self-resorting cannot be considered separate from the social and cultural context to which the individual belongs.

According to MacIntyre, a community must achieve a common project to bring about some good recognized as a shared good by all those engaging in the project [4] (p. 151). A community may support a sense of self by acknowledging the idea of identity. In other words, identity can be socially constituted in a community. However, Sandel argues that the self is not unified or unitary, and he considers identity formation as a central good or public act rather than as a search for the soul [5]. However, this should be distinguished from collectivism. A community pursues individual freedom and community values based on equality. MacIntyre refers to the self as "self-detached" from the group [4] (p. 205). In other words, for Morrison, a community in which the self can be formed or realized is a true community. Therefore, it is a social philosophy that emphasizes the importance of society in articulating the good or virtuous in contrast with liberalism. Thus, the concept of the self "as a being prior to its ends" [5] (p. 86) in liberalism is often criticized by communitarians. Communitarians' ideology often promotes the ideal of the common good of a society. Within the framework of communitarianism, Sula and Nell participate in a community so as to share the common good and to be in harmony with each other within a Black community. However, it is also understood that communitarianism finds the foundational basis for its social and political ideas in an individualist tradition [23] (pp. 70-71). The essence of the individual is understood to be achieved in and as a community as described in Sula.

\section{A Community and the Other in Beloved}

A community is made up of people in different situations and different spheres of existence by the reciprocal recognition of individuals. It should embrace a variety of human situations and diverse ways of life and existence. However, the idea of the relationship between human rights and community is different from the views of communitarianism and individualism.

Beloved explores the link between the distortion of identity and community. The dehumanization experienced by slaves causes the characters of Beloved to lose their sense of self. This novel describes the necessity or importance of communal participation for Black individuals. It is also natural that the other can be different from the self-due to otherness [24], (p. 106). Toni Morrison's Beloved may be taken as discourse of the other in Lacanian theory [25]. Lacan criticizes Descartes's "cogito ergo sum": I think; therefore I am, asserting that "I think where I am not, therefore I am where I do not think" [26] (p. 166). This implies that " $\mathrm{I}$ " can exist in "the other" without being aware of conscious thought; as a result, it is susceptible to a blurring of identity [25] (pp. 337-338). Lacan explains "without being aware of conscious thought" as "a repressed but organized and intelligent discourse of the other" [27] (p. 99). The inoperative community can be realized in one's relationship 
with others. It is important to restore an individual's identity, but their relationship with others is more important.

Beloved is a story of an individual, but also of a collective memory. On an individual level, Morrison creates a space in which a mother tells her story and asserts herself as a mother, and she argues for maternal love. On the other hand, on a collective level this novel is about the unnamed people who suffered from slavery. It explores the inner self of a slave woman and delves into Black motherhood and subjectivity.

Morrison deals with self-satisfied motherhood, the confusion of identity, and the spirit of conflict and reconciliation with the Black community as Sethe, a slave who escaped in this novel, established in the process of obtaining freedom. Sethe tries to talk to her baby's spirits while Grandma Baby is dead, leaving only herself and Denver. However, Sethe seems to be talking to a lovely young daughter like Denver, rather than talking to a ghost. Despite the fact that the ghost does not agree with motherhood, Sethe thinks that her behaviors were justified, that she can forgive and then reconcile.

Sethe and Denver decided to end the persecution by calling forth the ghost that tried them so. Perhaps a conversation, they thought, an exchange of views or something would help. So, they held hands and said. "Come on. Come on. You may as well just come on."

The sideboard took a step forward but nothing else did. "Grandma Baby must be stopping it." ... "I doubt that." She said. "You are forgetting how little it is." (Beloved, pp. 4-5)

Sethe undertakes a dangerous escape despite the fatigue caused by a schoolteacher's physical abuse and her impending pregnancy. The reason she escapes despite these risks is to regain her motherhood, which she has been deprived of as a Black woman.

Nobody will ever get my milk no more except my own children. I never had to give it to nobody else. (Beloved, p. 236)

The main reason for Nan to save only Sethe was that Sethe was the only child born of the pure love of Black people, whereas the other children were born from the rapes of sailors or White people. This development shows Morrison's pure love for Black individuals. Sethe wants to give her endless love to Beloved. However, her thirst for motherhood increases to a strong and possessive level despite her efforts.

I am Beloved and she is mine.... I am not separate from her there.... her face is my own and I want to be there in the place where her face is and to be looking at it too a hot thing. (Beloved, p. 243)

Denver's feelings about her mother include not only fear but also tolerance. Her monologue reveals her intention to forgive her mother's self-fulfilling motherhood on behalf of Beloved's mind. Denver's communication with a Black community makes Sethe's suffering not that of an individual but that of the entire Black community. However, once the pain is shared with others, it can be removed [28] (p. 321). The origin of the pain is the dominant culture's unwillingness to allow the subjugated culture the right to self-definition, and self-discovery, and, when they deem it necessary, self [28] (p. 321).

Within the framework of Lacan's theory of "the other", Sethe's subject is her double more than herself, and her identity appears as Beloved, as her alternative character, "the other" [25] (p. 338).

Morrison portrays the life of a Black woman in Beloved, emphasizing the need for interaction between men and women and showing a vision that encompasses both men and women [29] (p. 125). The self-consciousness needed to recover the wounded self, the community spirit needed to heal each other's suffering, and the partnership between men and women has implications for the community. The Black community, with conflicts based on class and gender differences, is a mental heritage to be remembered and preciously inherited from the lives of ancestors. The Black person suffering from unbearable humiliation and physical injury as a human being in a white-centric society avoids remembering and 
speaking of slavery. For African Americans, however, slavery is a source of all physical and mental injuries, but in order to escape from the pain, it is necessary to have an independent Black spirit that faces or confronts reality. Above all, Morrison emphasizes the importance of the Black community as a realization of coexistence through cooperation and bonding with white people. Morrison, of course, warns against ostracism, a postcolonial thought that focuses on resistance and struggle against the dominant. Black people seek to restore their language and culture before they suffer oppression from the dominant culture, but they must acknowledge the multicultural hybrids in a multicultural society and interbreed and cooperate with heterogeneous elements. A community that lives in harmony with heterogeneous lives will be the kind of society Morrison pursues in Beloved. In other words, an individual's true self-realization and securing identity are possible when he or she acts as a member of the community.

In the Nancian sense, an individual is the basic unit of community, "self" is constantly dismantled, and existence is acknowledged when there is an "other" in a community. Additionally, community is made up of individuals that are not subject to any artificial intervention. The relative concept of otherness does not have any ideology or politics. It comes from being with others. The other can be reflected into Beloved in Black community as her unconscious voice and a strong bond with herself being a part of motherhood. It is not a compulsory or repressed state but arises from an inoperative community. Human beings must always be open to those who are not themselves. Beloved is not a being of freedom, but a being-with constrained by others to which they are related in Black community. However, it is the finitude that can reach the sense of self due to its limitations. Our existence is neither mine nor the existence of others. For Morrison, existence is also ethical because it is constituted by others. In Beloved, Morrison also emphasized that a being-with is not a question of an other. A being is always constituted by relationality as in Nancy's view. In other words, an individual constituted by others, which the community has a duty toward. Morrison highlights the importance of self-worth within the boundary of community, reclaiming the development of Black identity. In the Nancian sense, it is communicated through sharing the finitude of others. As pointed out earlier, Beloved tells the link between the distortion of identity and community. It explores the necessity of communal participation for individuals with the relation of others within Black community.

\section{Epiphany as Black Identity and in a Community}

Toni Morrison gradually expanded her readership with African American novels. Morrison has contributed greatly to the "second renaissance" of American novels [30] (p. 21). In her efforts to overcome the existing negative stereotypes of Black women, she does not create another ideal model, but solves racial issues and identities from their own perspective as Black women. Morrison is a representative Black female writer who delicately embodies the dilemma of Black people who want to preserve Black historical and cultural identity while embracing the values of the White dominant culture and promoting economic development. According to Skerrett, Morrison's work world successfully absorbed the lessons of "magical realism" in Latin America in a modernist tradition, with an abundance of imagination and an excellent reproduction of Black women and their surroundings [31] (p. 192). She criticizes the attitudes of the Black community during the Civil Rights Movement in "Rediscovering Black History", claiming that Black people have forgotten their collective identity and community consciousness. In other words, Morrison shows the various ways in which Black people can be fully assimilated into the values of the dominant society, and that they observe the extreme tendencies that only adhere to the unique racial and cultural identities of African Americans. This emphasizes the need to critically select and accept values. In other words, she focuses on the importance of community through the recovery of self-identity and the acceptance of others. Thus, Morrison's interest in the community emerges as an American Black history writing work that reconstructs the past experiences of Black people. 
Through The Bluest Eye and Sula, Morrison emphasizes racial and gender issues as problems of the survival of Black communities by highlighting the growing process of Black women. Another novel of hers, Song of Solomon (1977), has been considered as a Bildungsroman [32] (p. 419), in that the protagonist realizes his identity and experiences a true epiphany; it is also seen as a saga novel, because it covers a Black family's historical quest. Morrison borrows the Icarus myth in this novel, which is a new adaptation of Greek mythology. It is transformed into a setting where the quest for freedom must fail because of the social oppression and suffering of Black people, not the failure of human arrogance.

Song of Solomon consists of two parts and fifteen chapters in total. It follows the life of Macon Dead III, an African American man living in Michigan, from birth to adulthood. In part one, it deals with the life of Milkman, who has an unstable identity due to the disruption of family and community ties under the absolute influence of Macon Dead Jr. Additionally, part two deals with the process of acquiring the identity of a Black American by searching for the roots of ancestors, with various stories handed down from various characters who have met in the south. The novel, which consists of numerous episodes, is in a setting where Milkman is at the center of a community that has been marginalized, listening to the hidden stories of the family that he accidentally hears and wandering spiritually. The short epigraph shown at the beginning of the novel is closely related to the myth of emergency, the main motif of the novel. This is a compressed version of the theme of the novel. In other words, Morrison emphasizes that this enables the Black community to value the bond based on the myth of Black identity and acquire the heritage of its name.

The community that Morrison seeks might be an imaginary one that does not exist in reality, as Nancy finds in myths. Morrison's community in Song of Solomon does exist in the mythology of immanentism presented by Nancy. For Nancy, to make a dichotomy between community and individuality is not necessary because these cannot be separated from each other and an autonomous individual is only possible within a community.

Morrison also reveals that the communal desire for identity is closed and undivided as in Nancy's immanentism. She describes the reclamation of identity for Black community and its establishment derive from the search of self by learning about the past of the Black community. It is neither divided nor open. In Song of Solomon, the Black woman is not a being trapped in a small world of "self", but an embodiment of a generative desire that constantly undergoes transformation within herself. Morrison also argues that to know the past of the Black community is to achieve their black identity since both Morrison and Nancy view how communities unite around undivided egos by striving to protect their identities from the influence of others.

Whether this consciousness conceives of itself as effectively retrospective or whether, disregarding the realities of the past, it constructs images of this past for the sake of an ideal or prospective vision. We should be suspicious of this consciousness first of all because it seems to have accompanied the Western world from its very beginnings: at every moment in history, the Occident has rendered itself to the nostalgia for a more archaic community that has disappeared, and to deploring a loss of familiarity, fraternity and conviviality. Our history begins with the departure of Ulysses and with the onset of rivalry, dissension, and conspiracy in his palace. Around Penelope, who reweaves the fabric of intimacy without ever managing to complete it, pretenders set up the warring and political scene of society-pure exteriority. [16] (p. 10)

Nancy describes immanentism as the horizon of attitudes towards identity and community. For Morrison, community is a will to immanence. Death is ecstatic toward the other, which is a being-with. In other words, death reveals community, since it is not the infinite of the individual as in Song of Solomon. A community is the event of being-with, and death must assume it cannot be made a work.

Community no more makes a work out of death than it is itself a work. ... Community is calibrated on death as on that of which it is precisely impossible to make a work. [16] (p. 15) 


\section{Conclusions}

This paper focused on Toni Morrison's novels regarding the relationship between the individual and community in the framework of the intersectional character of literature and human rights - that is, the meaning of self-formation and community. Human rights are in some ways linked to community. From the communitarian perspective, there should be some symbolic, shared experiences and actions, and some integrations that are selfregulating [33] (p. 449). Human rights in the liberal tradition, then, essentially become the rights of individuals [34] (p. 182). However, human rights are surely ascribed to individuals by other individuals, and radical communitarianism offers space for addressing some of the problems emanating from the liberal framework of rights by viewing the human being as an object of moral care in the community [35] (p. 500).

The racial community has emerged as a basis for Black identity to counteract the oppressive and unjust force of the dominant society in the 1950s and 1960s. During the Black Movement of the Civil Rights Era, an individual's sense of self was formed through relationships with others as a process of individuation. In works of African American literature, Toni Morrison emphasizes the concept of community not as a distinction between individuals and groups but as a neighborhood between the self and others, which is used to build a community that goes beyond racial and gender boundaries. In a general way, Morrison explores Black identity as a framework through which a community might consider the complex relationship between the self and the other in her novels. In doing so, her perspective on the conjuncture of literature and human rights draws on the essential insights of postcolonial study and communitarianism. The differing modes of the human being's aestheticism on offer in her novels do not necessarily resolve the philosophical issues at stake for human rights.

Toni Morrison probably sees a problem with the relationship between community values and the personal value of human rights. She indirectly deals with human rights issues or promotes human rights within the framework of a Black community or an imaginary community to emphasize loving the self and embracing others. In other words, she highlights the importance of self-worth within the boundary of a community, reclaiming the development of Black identity.

Morrison's novels do not claim the rights of oppressed Blacks, but rather describe the general human psychology of oppressed and desperate people, ultimately showing their hope. Morrison, however, recognizes the history and identity of African Americans and represents a more universal and comprehensive developmental-themed consciousness of the unity of the whole human community.

In the history of America, a person's demand for freedom and democracy against racial discrimination and segregation usually aims at seeking human rights and restoring identity.

My tendency is to focus on neighborhoods and communities. And the community, the black community-I don't like to use that term because it came to mean something much different in the sixties and seventies, as though we had to forge one-but it had seemed to me that it was always there, only we called it the "neighborhood." And there was this life-giving, very, very strong sustenance that people got from neighborhood. [22] (p. 11)

The Black community that Morrison describes is a space where Black culture, the heritage of neighbors and ancestors, exists. Morrison states that this is the value of the community, standing for African American values. The neighborhood that she refers to is a concept that distinguishes it from the concept of a Black community that had been formed for the unity of Blacks during the human rights movement in the 1960s. She emphasizes that this neighborhood is a traditional Black community that cares and nurtures its members and provides spiritual nourishment. The concept of community that Toni Morrison describes may be very abstract. The imaginary community she describes may not be specific. Nevertheless, it does not seem to deny the existence of a specific community, as found in communitarianism. In other words, a community is necessary but Morrison does 
not specify the nature of the community. Perhaps, it is the Nancian community that exists only through relations with others.

Author Contributions: Conceptualization, T.K.; writing—original draft preparation, T.K.; writingreview and editing, S.K.; supervision, T.K. and S.K.; funding acquisition, T.K. and S.K. All authors have read and agreed to the published version of the manuscript.

Funding: This work was supported by the Hankuk University of Foreign Studies in 2020" and "This work was also supported by a National Research Foundation of Korea Grant funded by the Korean Government (NRF-2017S1A6A3A02079749).

Acknowledgments: The authors are grateful to the anonymous reviewers for their insightful comments and suggestions.

Conflicts of Interest: The author declares no conflict of interest. The funders had no role in the design of the study; in the collection, analysis, or interpretation of data; in the writing of the article; or in the decision to publish the results.

\section{References}

1. Kim, C. What is justice. Korean J. Soc. Theory 2011, 39, 37-41.

2. McDonald, M. Should Communities Have Rights? Reflections on Liberal Individualism. Can. J. Law Jurisprud. 1991, 4, 217-238. [CrossRef]

3. Narveson, J. Collective Rights? Can. J. Law Jurisprud. 1991, 4, 329-345. [CrossRef]

4. MacIntyre, A. After Virtue: A Study in Moral Theory; University of Nortre Dame Press: Notre Dame, IN, USA, 1981. Available online: https: / / epistemh.pbworks.com/f/4.+Macintyre.pdf (accessed on 8 July 2018).

5. Sandel, M. Liberalism and the Limits of Justice; Cambridge University Press: Cambridge, UK, 1982.

6. Walzer, M. Thick and Thin: Moral Argument of Home and Abroad; University of Notre Dame: Notre Dame, IN, USA, 1994. Available online: http:/ fs2.american.edu/dfagel/www/Philosophers/Walzer/Thick-and-Thin-Chapter\%20One_Moral\%20 Minimalism.pdf (accessed on 8 July 2018).

7. Taylor, C. Atomism. In Philosophy and the Human Sciences: Philosophical Papers; Taylor, C., Ed.; Cambridge University Press: Cambridge, UK, 1985; Volume 2.

8. McBride, K.D. Postliberal Politics: Feminism, Communitarianism, and the Search for Community. Ph.D. Thesis, University of California, Berkeley, CA, USA, 1999.

9. Gusfield, J.R. Community: A Critical Response; Harper Colophon Books: New York, NY, USA, 1975.

10. McMillan, D.W.; Chavis, D.M. Sense of Community: A Definition and Theory. J. Community Psychol. 1986, 14, 6-23. [CrossRef]

11. Doolittle, R.J.; MacDonald, D. Communication and a sense of community in a metropolitan neighborhood: A factor analytic examination. Commun. Q. 1978, 26, 2-7. [CrossRef]

12. Glynn, T.J. Psychological sense of community: Measurement and application. Hum. Relat. 1981, 34, 780-818. [CrossRef]

13. Bachrach, K.M.; Zautra, A.J. Coping with a community stressor: The threat of a hazardous waste facility. J. Health Soc. Behav. 1985, 26, 127-141. [CrossRef] [PubMed]

14. Bowring, B. Misunderstanding MacIntyre on Human Rights. Anal. Krit. 2008, 30, 205-214. [CrossRef]

15. Miller, D. Cosmopolitan Respect and Patriotic Concern. Philos. Public Aff. 1998, 27, 202-224. [CrossRef]

16. Nancy, J.L. The Inoperative Community; Translated Version Used, 2010; University of Minnesota Press: Minneapolis, MN, USA, 1983.

17. Gilkes, C. Holding Black the Ocean with a Broom: Black Women and Community work. In The Black Woman; Rodgers-Rose, L.F., Ed.; Sage: Beverly Hill, CA, USA, 1980; pp. 2017-2232.

18. Samimi, Z.; Taebi, Z.; Azari, M. To get rid of Funkiness: Cross-Cultural conflicts in Morrison's Sula and The Bluest Eye. Int. Refereed e-J. Lit. Explor. 2017, 5, 45-55.

19. Mayberry, N.S. Something Other than a Family Quarrel: The Beautiful Boys in Morrison's Sula. Afr. Am. Rev. 2003, 34, 517-533. [CrossRef]

20. McDowell, D.E. The Changing Same: Black Women's Literature, Criticism, and Theory; Indianan UP: Bloomington, IN, USA, 1995.

21. Watkins, S. Twentieth-Century Women Novelists: Feminist Theory into Practice; Palgrave: Houndmills, UK, 2001.

22. Parker, B.J. Complexity: Toni Morrison's Women. In Conversation with Toni Morrison; Morrison, T., Taylor-Guthrie, D.K., Eds.; UP of Mississippi: Jackson, MS, USA, 1994; pp. 60-66.

23. Sirkku, K.H. Human rights in Africa: From communitarian values to utilitarian practice. Hum. Rights Rev. 2004, 5, 61-85.

24. Viola, F. Personal Identity in the Human Rights Perspective. In Law, Justice and the State: Essays on Justice and Rights; Peczenki, A., Karlsson, M.M., Eds.; Franz Steiner Verlag: Stuttgart, Germany, 1995; Volume 1, pp. 100-109.

25. Hong, S. Toni Morrison's Beloved: The discourse of the Other. Comp. Study World Lit. 2008, 22, $337-347$.

26. Lacan, J. Écrits: A Selection; Norton: New York, NY, USA, 1977.

27. Ragland-Sullivan, E. Jacques Lacan and the Philosophy of Psychoanalysis; University of Illinois: Urbana, IL, USA, 1987. 
28. Rushdy, A.H.A. Rememory: Primal Scenes and Constructions in Toni Morrison's Novels. Contemp. Lit. 1990, 31, $300-323$. [CrossRef]

29. Ferguson, R. History, Memory and Language in Toni Morrison's Beloved. In Feminist Criticism: Theory and Practice; Sellers, S., Ed.; University of Toronto Press: Toronto, ON, Canada, 1991; pp. 109-127.

30. Gillespie, D.; Kubitschek, M.D. Who Cares? Women-Centered Psychology in Sula. Black Am. Lit. Forum 1990, 24, 21-48. [CrossRef]

31. Skerrett, J. Recitation to the Griot: Storytelling and Learning in Toni Morrison's Song of Solomon. In Conjuring: Black Women, Fiction, and Literary Tradition; Pryse, M., Hortense, J.S., Eds.; Indianan UP: Bloomington, IN, USA, 1985; pp. $192-202$.

32. Royster, M.P. Milkman's Flying: The Scapegoat transcended in Toni Morrison's Song of Solomon. Coll. Lang. Assoc. J. 1982, 24, 419-440.

33. Selznick, P. The Idea of a Communitarian Morality. Calif. Law Rev. 1987, 75, 445-463. [CrossRef]

34. Howard, E.R. Group versus Individual Identity in the African Debate on Human Rights. In Human Rights in Africa: Cross Cultural Perspectives; An-Na'im, A.A., Deng, M.F., Eds.; The Brookings Institution: Washington, DC, USA, 1990; pp. $159-183$.

35. Ajei, M.O. Human rights in a moderate communitarian political framework. S. Afr. J. Philos. 2015, 34, 491-503. [CrossRef] 